\title{
Sakprosa anno 2016
}

\author{
Tidsskriftet Sakprosa \\ Bind 8, Nummer 3 \\ (C) 2016
}




\section{Redaksjonelt: Sakprosa anno 2016}

Da året 2016 opprant, var nobelpristildelingen til forfatteren Svetlana Aleksijevitsj nylig overstått. Litterært interesserte over hele kloden ble nå kjent med en ganske brutal og ytterst fascinerende, postsovjetisk prosa som «adressaten har grunn til å oppfatte som direkte ytringer om virkeligheten», for å sitere min egen sakprosa-definisjon. Når året nå er i ferd med å ebbe ut, er begrepet «post-factual society» på alles lepper, inspirert av en nyvalgt amerikansk president med et skamløst forhold til etterrettelighet, men sørgelig aktuelt verden over.

Begrepet «sakprosa» finnes verken på russisk eller engelsk. Men det nordiske begrepet er etisk potent og kan gjerne bli eksportvare. For det første fordi det setter sak og saklighet i sentrum, og for det andre fordi det legger vekt på prosaens kvaliteter og dermed ikke negativt omtaler sakens tekstunivers som blott og bar non-fiction.

Saklighet trengs, og kvalitetssakprosa trengs - innen alle sjangere. Årgangen av tidsskriftet startet med en diskusjon om krav til kvaliteter i den offentlige samtalen (Kock og Andersen). Så fulgte et knippe bidrag som på forskjellig vis utvider sakprosaforskingens perspektiv: Teksthistorisk nærlesning som vaksine mot mytologier (Roos), bruk av den unike samlingen bokhylla.no som litteraturhistorisk arkiv (Egeland), tegneserier som opplysning (Cortsen) og radiounderholdning som argumentasjon (Ulbæk). Som om ikke prosabegrepet dermed var tilstrekkelig utfordret, publiserte vi samtidig tidsskriftets første bidrag om sakpoesi (Claudi).

En av årets tre siste artikler (Dahl) vender delvis tilbake til sakprosabegrepets historiske utgangspunkt: Stilistikken. Men nå er perspektivet dialog, flerstemmighet og intertekstualitet, inspirert av den uoppslitelige russiske tekst-tenkeren Mikail Bakthin. Sakprosaen har lenge hatt en sterk stilling i 
norske læreplaner, til dels også i læremidlene. Men hva slags oppgaver gir lærebøkene elevene å arbeide med når de skal lese sakprosa - sammenliknet med skjønnlitteraturen? Det har Bakken \& Andersson Bakken undersøkt empirisk. Resultatet bør bli formidlet til læremiddelforlag over hele Norden med følgende beskjed: Den tid må være forbi hvor sakprosa formidles som om det var tran: vond smak, men påkrevet!

Men av og til er jo sakprosaen slik. Det kan nemlig synes som om nettopp dette er oppskriften på svenske firmaårsmeldingers erklæringer om goodwill, som undersøkes i en tankevekkende artikkel (Rahm og Sandell). I disse tekstene, som ofte trykkes på påkostet papir, praktiseres en form for copy\&paste-intertekstualitet som forfatterne kommenterer slik i artikkelens konklusjon: «Att skriva det man vet andra skrivit och åtminstone kommit undan med innebär en reducerad risk för att den egna texten ska utsättas för kritik.»

«Känslouttryck äro principielt uteslutna» i sakprosaen, slo begrepets far, Rolv Pipping, fast i 1938. Men som retorikeren alltid har visst: logos må ledsages av både etos og patos for at en ytring skal bli virksom. «Känslouttryck» hører selvsagt hjemme i sakens mangfoldige prosa. Men hvis sakprosabegrepet skal ha noen etisk, og ikke bare deskriptiv, mening, må det knyttes til en respekt for det etterrettelighetsregimet som demokratiet forutsetter: Vi må kunne stole på at politikeren, forskeren, læreren og alle de andre rolleutøverne forsøker å ytre seg etterrettelig om sak. Ellers blir situasjonen patetisk, slik den så ofte har utviklet seg det siste året.

Johan L. Tønnesson 